\title{
Instrumental Approach and Diagnosis of Total Inorganics in a Typical Carbonaceous Matter
}

\author{
*11ASUEN, G.O.; LUCAS. F.A; IMASUEN O.I.
}

Department Of Geology, University Of Benin, Benin City

Keywords: Instrumental Diagnosis, Total Inorganics, Carbonaceous Matter

\begin{abstract}
Typical Carbonaceous matter are often widespread and reveal relatively wide range of dominant organic types. The instrumental diagnosis to subject them to oxidation, combustion and/or incineration serve till date mandatory fundamental requirement in the further pursuance of their mineralogical and wet Chemical Analysis. The results of the Ash content from three (3) carbonaceous coal-and shaly coal samples from Northeastern England and Scottish fife show that the variation and/or the volatilization of the inherent sensitive elements are related to both the techniques and the sample composition. From the two techniques adopted, the high-and low-temperature methods the Ash values observed/obtained for Westfied shaly and Beaumont coal types are dependent on their derived material source-argillaceous and pure coal components. However, of the inorganic components (Ash) values that can be recovered from any carbonaceous matter, Radio-frequency method appears to suggest the accurate and reliable alternative for their subsequent geochemical appraisal. @JASEM
\end{abstract}

\section{http://dx.doi.org/10.4314/jasem.v17i3.5}

The carbonaceous deposits which record an economically important lithology such as coal, oil shales, coaly shale etc are characterized by their interesting mode of formation. These samples often times are subjected to oxidation and/or combustion revealing significant differences both in the amount and composition in their inorganics (Ash). The principal causes are not unconnected to both the varying degree of mineralization episodes and the operators variation in the analytical equipment used. However the majority of these inorganics are regarded as impurities conditioned by factors such as hydrological processes, proximity to source rock, environmental influence, topography etc. However separating the inorganics from their organic fractions is significant for subsequent mineralogical and chemical appraisal for any typical carbonaceous matter.

In reality, the inherent problems posed in obtaining absolute accuracy in inorganics for the needed further appraisal clearly recognize possible losses of volatile matter (i.e. sensitive elements) because such volatilization can't be clearly monitored under the subjected temperature regime. As a way out to achieving reliable and accurate inorganic data, for the pursuance of wet chemical and mineralogical analyses, the right instrumental techniques must compensate for the unavoidable losses so that the accurate/reproducibility of result can be guaranteed.

The two commonest instrumental techniques in use are, firstly the conventional high-temperature at $180^{\circ} \mathrm{C}$ via $490^{\circ} \mathrm{C} \pm 20^{\circ} \mathrm{C}$, [B.S. 1016 , part 3, (1)], obtain inorganics with less accuracy because certain

*Corresponding author email: isaacokpes@yahoo.com elements are assumed to have undergone volatilization and therefore cannot serve to represent the direct equivalent of the total inorganics. Although estimating such inorganics is with the application of the modified Parr's formula, because adequate compensation of volatilized elements has to be assumed. The second method applies the radiofrequency low-temperature at approximately $110^{\circ} \mathrm{C}$ [Gluskoter, (1965) Gluskoter et al., (1977)] and assume no possible losses which is an indication of the retention of the volatile matter. Perhaps it is important to state that the radio-frequency method as the direct equivalent of total inorganics in carbonaceous matter is difficult if not impossible to achieve. However [Glukoter et al., (1977) O' Gorman (1971) and Miller et al., (1979)], proposes that the radio-frequency low-temperature $\left(<150^{\circ} \mathrm{C}\right)$ equipment to be a direct equivalent of the total inorganics is also been adopted for this study.

\section{MATERIALS AND SAMPLE PREPARATION}

The carbonaceous matter referred to in this study (coals, oil shales, shaly coals etc.) originate from the carboniferous sediment of Northeastern England and the Scottish fife (Fig. 1). From these locations, three (3) different carbonaceous matter were recovered across the great variation in the depositional environments. [Johnson, (1970)] described the section as the productive coal measure which varies between Lower and Middle measures while the overlying sections that is less workable as the Upper Measures. 
The characteristics features of the recovered samples from this productive section were identified as
Beaumont, Howick coals and Westfield, shaly coals (Table 1).

Table 1: Description of Carboniferous Carbonaceous Samples

\begin{tabular}{|l|l|l|l|}
\hline Stratigraphic Class & Locality & Variety & Remarks \\
\hline Westphalian & Northumberland coalfied & Beaumont coals & $\begin{array}{l}\text { Formation overlain by shale. A non-marine influence on a } \\
\text { progressively subsiding flood plain (i.e. a river of rivers). }\end{array}$ \\
\hline Namurian & Howick & Howick coals & $\begin{array}{l}\text { Formation overlain by limestone (i.e. marine influence on subsiding } \\
\text { coals). }\end{array}$ \\
\hline Namurian & Westfield Opencast site & Shaly coal & $\begin{array}{l}\text { Abundant sapropelic organic matter (i.e. predominantly derived } \\
\text { from algae). }\end{array}$ \\
\hline
\end{tabular}

The initial preparation/investigation carried out on 33 samples from Beaumont, 34 samples from Howick coals and 27 samples from Westfield shaly coals were subjected to crushing, grinding and pulverization to achieve a particle size of "through" $212 \mu \mathrm{m}$ mesh sieve. Further, ashing by conventional high-temperature and the Radio-frequency lowtemperature methods requires the use of an aliquote of approx $2 \mathrm{gms}$ of pulverized sample thoroughly mixed to ensure homogeneity as well as eliminate density separation of particles. More importantly, each sample is spread in the tray to allow for effective and maximum exposure of the surface and particle size area before ashing.

Instrumentation: Conventional High-Temperature Method The experimental techniques relating to the separation of inorganics from carbonaceous matter by the conventional method involves its oxidation to yield ash by the high-temperature method of $500^{\circ} \mathrm{C}$ up to $810^{\circ} \mathrm{C}$ using British Standard method, [BS1016, part 3, (1)]. This technique is known to be unsatisfactory because the treatment which subjects it to high-temperature oxidation tends to complicate its chemical reaction [O' Gorman and Walker Jr., (1971)] and [Mitchell and Gluskoter, (1976)]. The carbonaceous matter by its very nature is complex with the sensitive elements lost due to volatilization, and therefore the Ash values as the exact equivalent of the inorganic matter content are suspect and cannot be ascertained/guaranteed.

Radio-Frequency Low-Temperature Method: The low temperature asher 'Plasmaprep- 100' used to examine carbonaceous matter was designed by Nanotech (Thin Films Ltd.) Basically, the machine is connected to a commercial grade oxygen cylinder whose flowrate is regulated by a needle valve and observed on a flow meter (Fig. 2a). The machine used a radio-frequency ( $\mathrm{RF}$ ) electromagnetic field to produce an electrodeless ring discharge, thus activating oxygen is fed into a closed sample chamber. The oxygen, which is constantly passed into the chamber dissociates into a mixture of atomic and ionic species as well as into electronically and vibrationally existing states, oxidizes the organic phase (coal material) in which heat is dissipated exothermically. The maximum temperature that can be reached in this oxidation chamber is $110^{\circ} \mathrm{C}$ (manufacturer, personal communication 1982). The whole system is kept under vacuum and the gaseous products of oxidation, viz, carbon dioxide, water vapour, excess oxygen and ozone, are constantly removed by the rotary pump connected to the sample chamber (Fig. 2b). Ashing by this method require that the 2 grams of pulverized carbonaceous matter is inserted into oxidation chamber. For effective ashing, the small amount of sample trays is periodically withdrawn and stirred every 2-3 hours during the day, are left unstirred all night. The results of constantly turning over the oxidized upper coal surface exposes the unashed sample below to the same exothermic reaction. This approach is setout to cutting down the duration of ashing. The average total ashing time for a single sample is estimated to lie within $24 \mathrm{hrs}$. This period allowed complete elimination of the combustible matter of the coal. Ashing was conducted at optimum RF power of 50 watts as recommended by [Miller et al., (1979)]

From the recovered incombustible residue (Ash), the percentage inorganic content can be calculated using the formula:

$$
A=\frac{w_{3}-w_{4}}{w_{2}-w_{1}} \times 100
$$

Where;

$w_{1} \quad=$ weight tray and lid,

$w_{2} \quad=$ weight of tray, lid and sample,

$w_{3} \quad=$ weight of tray, lid and ash,

$w_{4} \quad=$ weight of tray (after ash is removed) and lid, and

$A \quad=$ percentage of ash 


\section{RESULTS AND DISCUSSIONS}

Table 2: Summary of Results for Ashing Techniques

\begin{tabular}{|l|l|l|l|l|l|l|}
\hline SAMPLE & METHOD & N* & MIN & MAX & $\begin{array}{l}\text { ARITH } \\
\text { MEAN }\end{array}$ & STD. DEV. \\
\hline Beaumont & HTA & 33 & 1.5 & 21.1 & 5.92 & 4.67 \\
Coals & LTA & 33 & 2.3 & 25.5 & 8.03 & 5.46 \\
\hline Howick Coals & HTA & 34 & 4.3 & 36.8 & 17.21 & 8.6 \\
& LTA & 34 & 8.0 & 52.1 & 24.5 & 12.2 \\
\hline Westfield & HTA & 27 & 14.7 & 64.9 & 54.24 & 6.15 \\
Shaly Coal & LTA & 27 & 57.7 & 83.8 & 73.16 & 7.34 \\
\hline
\end{tabular}

$\mathrm{N}^{*}$ Number of Samples

The Beaumont Coals high-temperature ash (HTA) varies between 1.5 and $21.1 \mathrm{wt}$ percent (dry basis), while the low-temperature ash (LTA) ranges from 2.3 to 25.5 wt percent (dry basis, Tab. 2). Plotting these ash contents derived from both methods does give a statistically significant correlation. Then the value of the correlation coefficient $r$ is +0.99 and the intercept value on the $\mathrm{x}$-axis is equal to 1 percent (Fig. 3). This correlation is readily explained by 1 percent ash content on the low temperature ash, shows that using the high temperature technique, no ash will be observed for these coals. [Gluskoter et al., (1973)], in their study of lllinois coals, found a similar correlation between the LTA and HTA which they interpreted to be loss of volatile elements associated with coal at high temperatures. This conclusion is also borne out by the present work, where the difference in the amount of volatility between the two principal methods used ranges between 0.4 and 4.8 percent (dry basis). Moreover the distribution of the ash generally show higher ash contents at top and bottom. The increases at these horizons are not unexpected where ash contents usually rise suggesting the influence of erosive processes of the neighbouring source material. Whereas some of these coals also demonstrate relatively less material input, evidence suggesting preferred leaching at the top and bottom of their collieries. On a general note, the variation in ash content could be attributed to mean differences in the amount of inorganic material input into the coal basin that were irregular in time and space.

The percentage ash contents show in Howick coals to vary in a manner similar to that of the Beaumont coals. The correlation coefficient (r) between the HTA and LTA is +0.96, and shows a slightly asymmetrical distribution that is also indicative of losses due to volatilization (Fig. 4). A comparison between the two methods is important to assess to vitalization behaviour of this coal, which varies between 0.2 and 17.8 percent dry basis. The amount of volatilizations of sensitive elements is significantly shown by these samples in which the ash contents are high. The important feature of this coal lies in its relatively higher ash content than those of the Beaument coals, which ranges between 4.3 and 36.8 percent for HTA and between 8.0 and 52.1 percent LTA (wt dry basis, Table 2). Although not conclusive, coals overlain by marine beds are characterized by higher ash contents than coals which non-marine roofs and this may be the tenable explanation for the higher ash contents in this area and which appears to be in agreement as suggested by [Francis, (1961)].

The Westfield shaly coals high-temperature ash content varied between 41.7 and $64.9 \mathrm{wt} \%$ dry basis and the low-temperature ash ranged from 57.7 to 83.8 wt\% dry basis (Table 2). The high ash contents of these samples could possibly be due to a basin where the erosive processes were exceptionally rapid. Comparison of these ash contents with those of the other coal types (i.e. Beaument and Howick) shows higher levels. This is not unexpected, considering also that it is more of a carbonaceous shale rather than an impure coal [ASTM, (1977)], [Swaine, (1967)] considered that carbonaceous material with an ash yield greater than $35 \%$ under standard conditions can only be termed 'coal'. Microscopical examination confirms also that the organic matter of the Westfield shaly coal seems to have inherited the clay-mineral fractions as discussed in [Asuen, (1988)]. In considering the relationship between the high temperature ash and low temperature ash, the correlation coefficient, $\mathrm{r}=+0.94$ and an intercept on the $\mathrm{x}$-axis of approximately $4.4 \%$ LTA, which is thought to relate to the amount of ash that can be retained by the low temperature method while it is volatilized in the high temperature method. It has been shown also that the majority of inorganic impurities is lowest in the Beaumont samples and highest in the Westfield samples (Table 3). The changes in the ash content from the former to the latter are probably dependent on the ash variation due to the variation in the source material component 
which is similar to the study proposed by [Dixon et al., (1964)]. Furthermore, the ashes of the different coal types exhibit significant differences in a number of ways, particularly, in the amounts obtained from the same coal subjected to both high-temperature and low-temperature methods. In all three coal types, it was clearly recognizable that the sensitive element/volatile matter has been lost and they readily increase with the increase in the total ash content.

Concluding Remarks: Ashing methods appear to be the most satisfactory approach at isolating inorganics from carbonaceous matter. Therefore, it is reasonable to assume that under a much lower temperature regime as it is case in this study (instrumentation) would retain most of the elements, particularly sensitive elements at relatively unaltered state.

The ash values obtained both in amount and composition due to oxidation/combustion demonstrate different results emanating from a single sample because of the different methods in use. However, the duplicate results from each method were in satisfactory agreement.

A small quantity (aliquot sample) selected for ashing were exposed to surface area oxidation attained true representation by harmonization of the entire bulk sample.

Accurate data analysis was given great emphasis rather than the speed by choosing the low temperature ash values as the recommended method for the pursuance of the mineralogical and wet chemical appraisal of any carbonaceous matter.

Ashing exercise to be repeated several times is recommended inorder to obtain the needed sufficient quantity for further complete geochemical analysis.

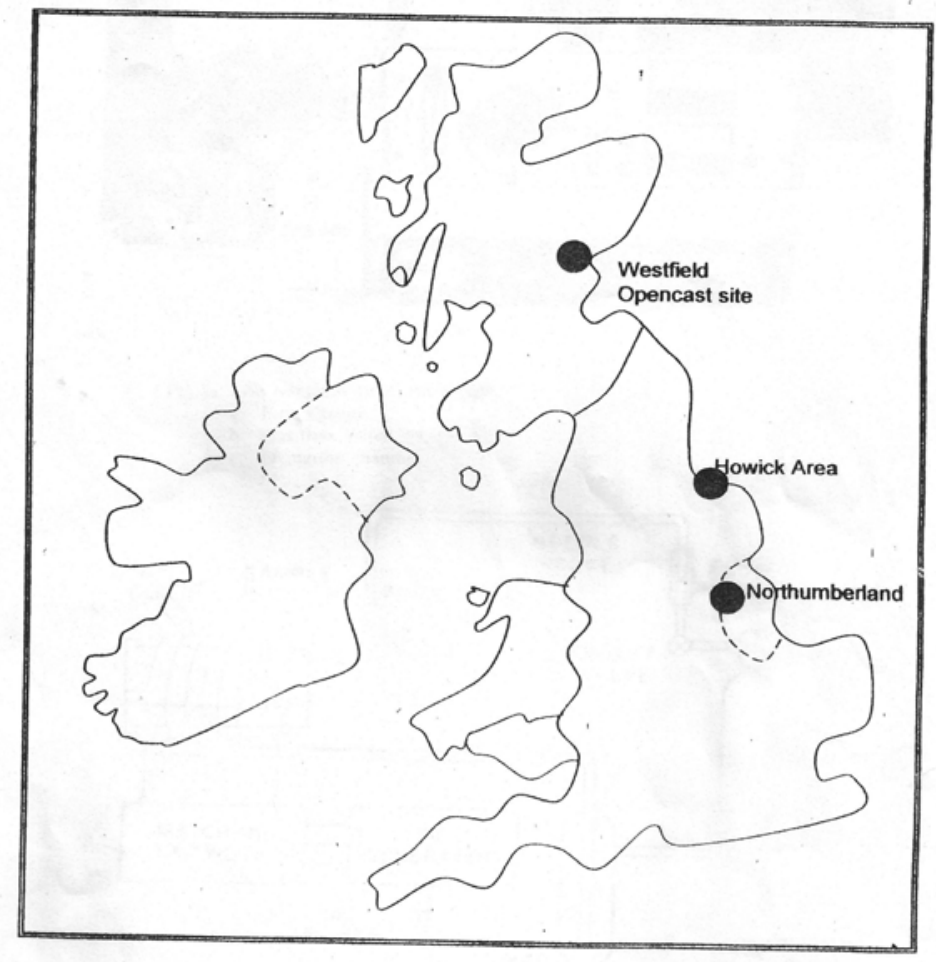

Fig: 1: Generalized sketch map of Great Britain showing the location of study area. 


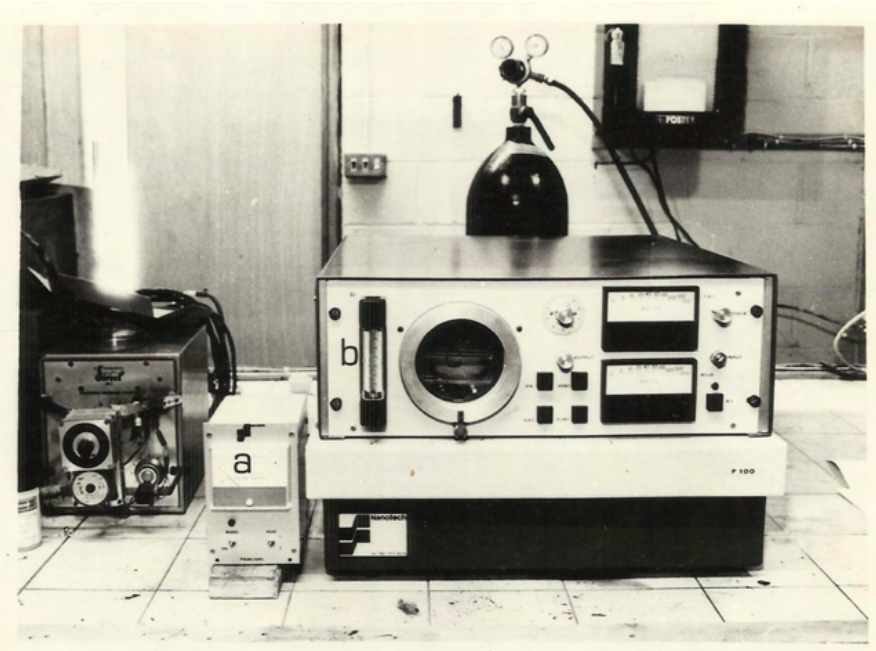

Fig: 2a Low temperature Plasmaprep-100

a. Pirani gauge

b. Gas flow meter

c. Oxidation chamber

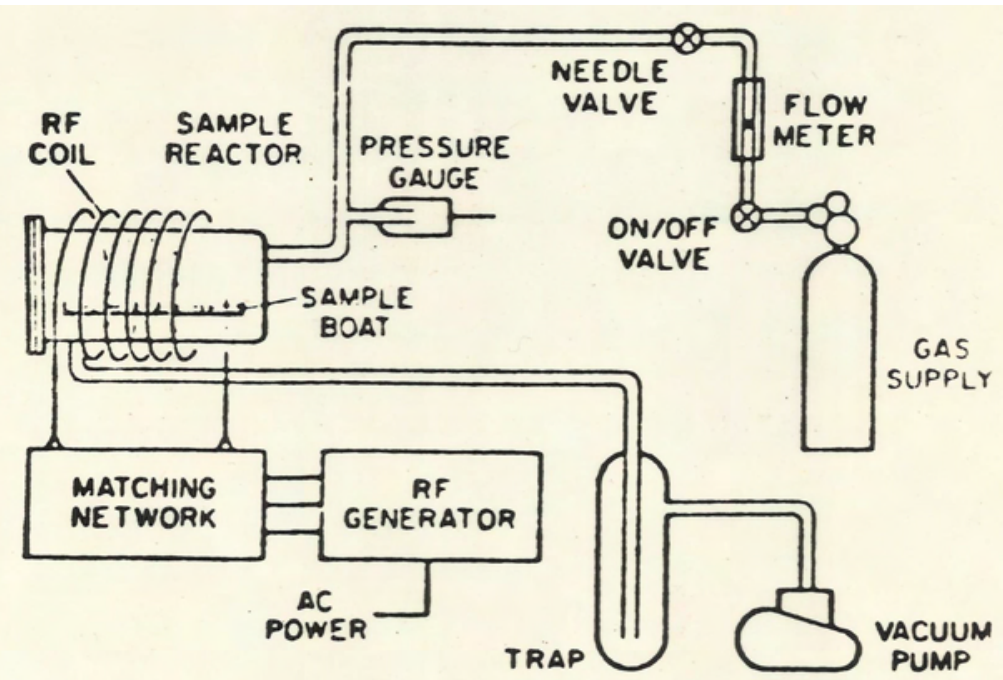

Fig:2b Schematic layout of the low temperature 'Plasmaprep-100' (from Hollahan 1974) 


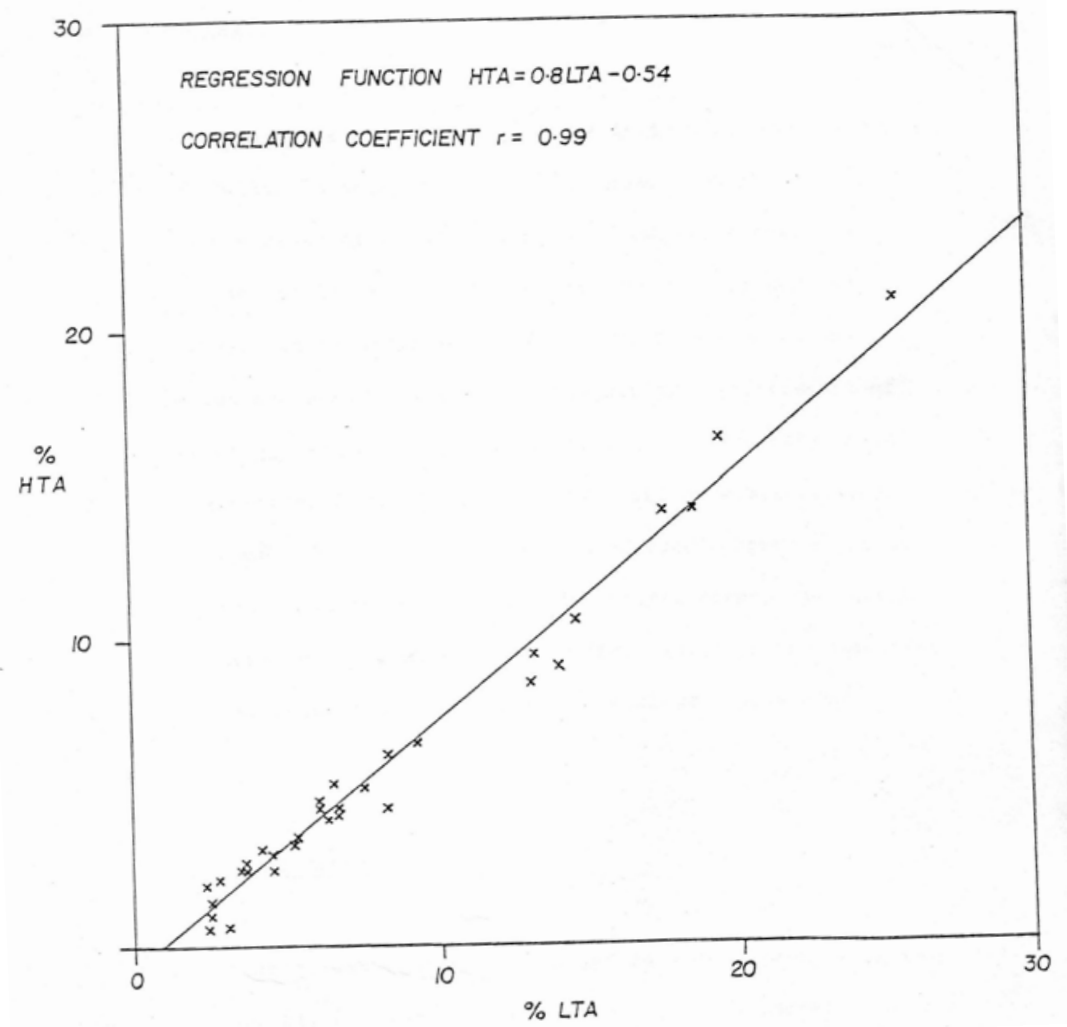

Fig: 3: Plot of high-temperature ash against low temperature ash for Beaumont coals

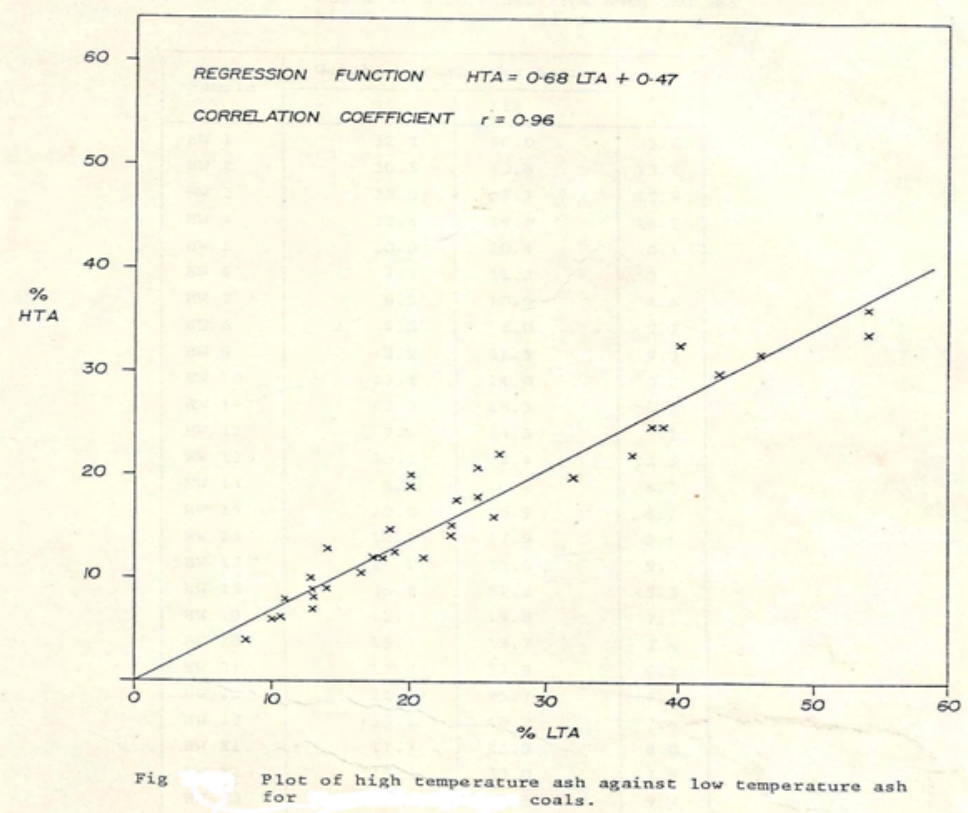

Fig: 4: Plot of high-temperature ash against low temperature ash for Howick coals 


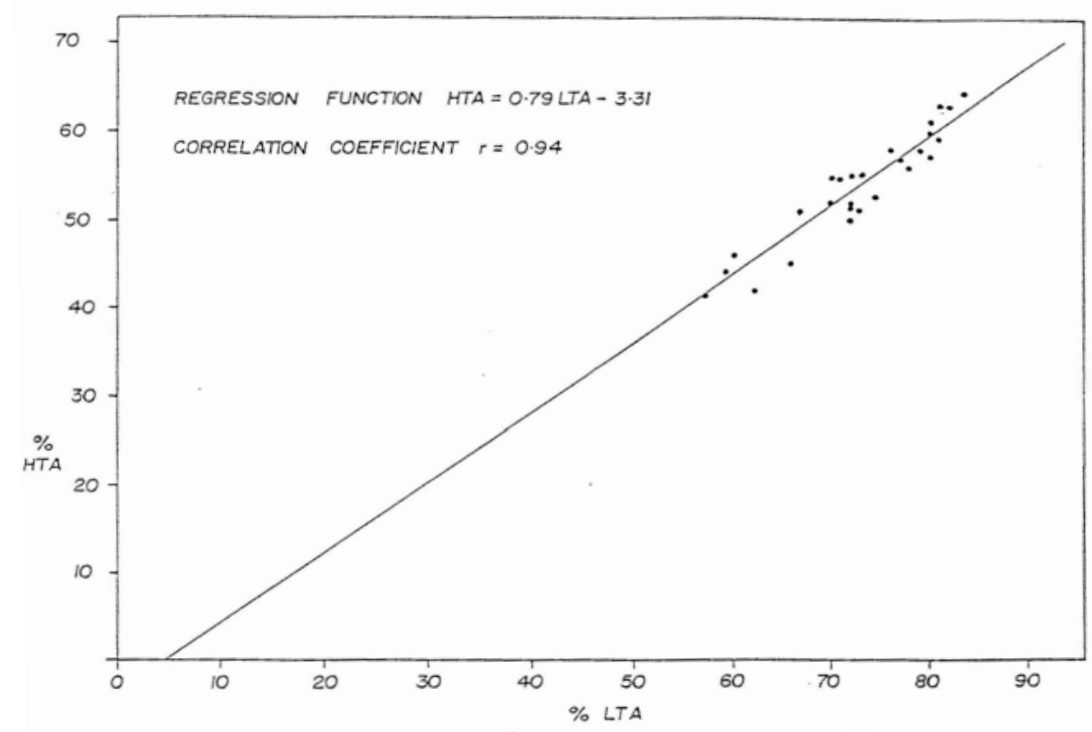

Fig: 5: Plot of high-temperature ash against low temperature ash for Westfield shaly coals

\section{REFERENCES}

America Society for Testing and Material (ASTM), 1977: Standard definition of term used for megascopic description of coal and coal beds and for microscopical description and analysis of coal. In: Annual Book of ASTM standards, Philadelphia Pa. Amer. Soc. Testing and Materials, Pt 26, 346.

Asuen G.O. (1988): Geochemistry of a Carboniferous oil shale from N.W.

Scotland. Jour. Sci. Tech. Series B, Vol. 2, Nr 1, 44.

British Standard Institution, 1957. Method for the Analysis and testing of coal and coke. Proximate analysis of coal. B.S. 1016, part 3.

Dixon, K., Skopsey, E., and Watt, H.K., 1964: The distribution and composition of inorganic matter in British coals. Part 1 - Initial study of the seam from the East Midland division of the National Coal Board. Jour. Inst. Fuel, 485.

Francis, W., 1961: Coal, its formation and composition $2^{\text {nd }}$ Edition Arnold Ltd., London 806p.

Gluskoter, H.J., 1965: Electric low-temperature ashing of bituminous coal.

Fuel. Vol. 44. Nr. 4285.

Gluskoter, H.J., Hatch, J.R., and Lindahl, P.C., 1973: Zinc in coals of the Illinois Basin. Geol. Surv. of
America. Abstract with Programs., Vol. 5, Nr 7, 637p.

Gluskoter, H.J., Ruch, R.R., Miller, W.G., Cahill, R.A., Dreher, G.B., and Kuhn, J.K., 1977: Trace elements in coals: Occurrence and distribution. Illinois State Geol. Surv. Circ. 499, 154p.

Johnson, G.A.L., 1970: Geology of Durham Country. Transc. Nat. Hist. Soc. of Northumberland, Vol. 41, 1.

Miller, R.N., Yarzab, R.F., and Given, P.H., 1979: Determination of the Mineral matter content of coal by low-temperature ashing. Fuel, vol 58,4 .

Mitchell, R.S., and Gluskoter, H.J., 1976: Mineralogy of ash of some American coals: variation with temperature and source. Fuel. Vol. 55, Nr 2, 90.

O’ Gorman, J.V. and Walker Jr, P.L., 1971: Mineral matter Characteristics of some American coals. Fuel. Vol. 50, 135.

O’ Gorman, J.V., (1971: Studies on Mineral matter and trace elements in North American Coals. Ph.D Thesis, University of the Pennsylvanian State. 184p.

Swaine, D.J., 1967: Inorganic Constituents in Australian coals. Sonderdruck aus den mitteilungen der Naturforschenden Gesellschaft in Bern - Nene Folge, 24, Band, 49. 